\title{
Structure and mechanical properties of Fe-25Al-5Zr and Fe-30Al-5Zr intermetallic alloys
}

Pavel Kejzlar

Institute for Nanomaterials, Advanced Technologies and Innovation, Technical University of Liberec, Studentska 1402/2, 46117 Liberec 1, Czech Republic. pavel.kejzlar@tul.cz

Iron aluminides are seen as promising candidates for high temperature structural materials to replace expensive nickel-chromium-based stainless steel. Due to their long-distance-ordered structure they exhibit some advantageous properties as an excellent corrosion resistance, low density, high specific stiffness and low raw material cost. On the other hand, they are inherently brittle at ambient temperatures and have insufficient high temperature strength and creep resistance. It has been shown that addition of $\mathrm{Zr}$ into Fe-Al-based material leads to precipitation hard ternary intermetallic phases which may enhance high temperature strength. Addition of 5 at. \% of $\mathrm{Zr}$ into the investigated alloys leads to formation of $\lambda 1$ and/or $\tau 1$ phase which have a significant effect on the $\sigma 0.2$ yield stress. In this paper, light optical microscopy, scanning electron microscopy, X-ray diffraction and high temperature pressure test were used to characterize the structure and mechanical properties of Fe-25Al$5 \mathrm{Zr}$ and Fe-30Al5-Zr alloys in as cast state and after heat treatment.

Key words: Iron Aluminides, Intermetallics, Structure, High temperature mechanical properties

\section{Acknowledgement}

The research has been supported by the SGS project "Innovation in Material Engineering”.

\section{References}

[1] LIU, C.T., et al. (1997). Ordered intermetallics alloys: an assessment. Intermetallics, Vol. 5, pp. 579.

[2] MCKAMEY, C.G., et al. (1991). A review of recent developments in Fe3Al-based alloys. J. Mater. Res., Vol. 6, No. 8, pp. 1779.

[3] STOLOFF, N.S., LIU, C.T. (2000) Microstructure and properties of materials (Volume 2), pp. 139-176. Ed. Li J.C.M.

[4] DEEVI, S. C., SIKKA, V. K. (1996). Nickel and iron aluminides: an overview on properties, processing, and applications. Intermetallics. Vol. 4, pp. 357.

[5] MORRIS, D.G. (1998) Possibilities for high-temperature strengthening in iron aluminides. Intermetallics. Vol. 6, p. 753.

[6] PALM, M. (2005). Concepts derived from phase diagram studies for the strengthening of Fe-Al-based alloys. Intermetallics. Vol. 13, pp. 1286.

[7] CIESLAR, M., KARLÍK, M. (2007). Carbide formation in Zr-containing Fe3Al-based alloys. Materials Science and Engineering. A 462, pp. 289.

[8] MORRIS, D.G., MUÑOZ-MORRIS, M.A., REQUEJO, L.M. (2006) New iron-aluminium alloy with thermally stable coherent intermetallics nanoprecipitates for enhanced high-temperature creep strength. Acta Materialia. Vol. 54, pp. 2335.

[9] STEIN, F., SAUTHOFF. G., PALM, M. (2004). Phases and Phase Equilibria in the Fe-Al-Zr System. Z. Metallkd. 95(6), pp. 469.

[10] RAGHAVAN, V. Al-Fe-Zr (Aluminium-Iron-Zirconium). (2006). Journal of Phase Equilibria and Diffusion. Vol. 27, No. 3, pp. 284.

[11] RAGHAVAN, V. Al-Fe-Zr (Aluminium-Iron-Zirconium). (2010). Journal of Phase Equilibria and Diffusion. Vol. 31, No. 5, pp. 459.

[12] GUO, C., et al. (2008). Thermodynamic description of the Al-Fe-Zr system. Calphad, Vol. 32, pp. 637.

[13] RIGAUD, V., et al: Thermodynamic assessment of the Fe-Al-Zr phase system. Calphad, 2009, Vol. 33, pp. 442.

[14] STEIN, F., PALM, M., SAUTHOFF, G. (2005). Structure and stability of laves phases part II-structure type variation in binary and ternary systems. Intermetallics. Vol. 13, pp. 1056.

[15] SAUTHOFF, G. (2000). Multiphase intermetallic alloys for structural applications. Intermetallics. Vol. 8, pp. 1101. 
[16] WASILKOVSKA, A., et al. (2004). Plastic deformation of Fe-Al polycrystals strengthened with Zr-containing Laves phases: I. Microstructure of undeformed materials. Materials Science and Engineering. A 380, pp. 9.

[17] WASILKOVSKA, A., et al. Plastic deformation of Fe-Al polycrystals strengthened with Zr-containing Laves phases: II. Mechanical properties. Materials Science and Engineering, 2004, A 381, pp. 1.

[18] STEIN, F.; PALM, M. SAUTHOFF, G. (2005).Mechanical properties and oxidation behaviour of two-phase iron aluminium alloys with $\mathrm{Zr}(\mathrm{Fe}, \mathrm{Al}) 2$ Laves phase or $\mathrm{Zr}(\mathrm{Fe}, \mathrm{Al}) 12 \tau 1$ phase. Intermetallics. Vol. 13, pp. 1275.

[19] KEJZLAR, P., KRATOCHVÍL, P. (2010). Examination of the structure and the phase composition of the alloy Fe30Al5Zr. Manufacturing technology. Vol. 10, pp. 70.

[20] KRATOCHVÍL, P., et al. (2012). The effect of Zr addition on the structure and high temperature strength of Fe30 at.\% Al type alloys. Intermetallics. Vol. 20, pp. 39.

[21] KEJZLAR, P.; KRATOCHVÍL, P.; VODIČKOVÁ, V. (2012). The effect of heat treatment on the structure of Fe-25Al-xZr alloys. In METAL 2012. Ostrava: TANGER, Ltd., 2012. CD-ROM. ISBN 978-80-87294-29-1.

[22] KEJZLAR, P. (2012). Fe-Al-Zr alloys for high temperature use. In JuveMatter 2012. Praha : Nakladatelství ČVUT. pp. 72. ISBN 978-80-01-05073-6.

[23] KEJZLAR, P. (2012). Intermetalické slitiny na bázi Fe-Al-Zr pro vysokoteplotní použití. In Workshop pro doktorandy FT a FS Světlanka 2012. Liberec : Technical University of Liberec. pp. 186. ISBN 978-80-7372-765-9. 